\title{
Coping Strategies of Food Insecure Households: The Case of Offa District, Wolaita Zone, South Nations Nationalities and Peoples Region
}

\author{
Mesele Woldemichael \\ Department of Civics and Ethical Studies, College of Social Sciences and Humanities, \\ Wolaita SoddoUniversity, Wolaita Soddo, Ethiopia
}

\begin{abstract}
Background: Ethiopia is one of the low income countries encountering food insecurity for decades due to unsatisfactory livelihood strategies and in the long run it may cause severe damage to livelihoods of the poor, thereby reducing self-sufficiency.

Objective: To assess and generate specific data on coping strategies of food insecure households in Offa district wolaita zone, SNNPR.

Methods and materials: Cross sectional community based study comprised of both primary and secondary data. A sampling procedure was used to randomly select representative farm households from each kebeles. The study was applied a simplified formula of Yamane and 125 farm households were selected as sample and primary data were collected using questionnaire.

Result: The study revealed the major perceived causes of food shortage were shortage of land, shortage of water, climatic problem, and lack of input supply. The traditional farming practice, poor performance and health condition of farmers, unemployment, lack of soil fertility etc also affect them. As study predominantly the first victims are children. According to the study, the actual household income in the study area did not meet the average minimum subsistence requirement. The major coping mechanisms and people solve their temporary problem of food shortage by using different types of coping mechanisms such as engaging in labor work, livestock sale, migration to urban areas, relaying on remittance from relatives, sale of wood and charcoal, reducing food consumption and requesting grain loan. Beyond these some local NGOs and GOs providing them by giving financial aid, credits services, participating in small business, job opportunity for unemployment's, awareness rising on use of technology, saving and family planning in the study area.

Conclusion: The current coping strategies are not sufficient because of they are also predominantly top down, and fail to bring the desired change in the life of the households. The findings of this study ensured that household livelihoods are highly diverse and policy-makers need to reflect on the most suitable ways of supporting this diversity.
\end{abstract}

Keywords:- causes, challenges, coping strategies, food insecurity, production, vulnerable group

DOI: $10.7176 / \mathrm{DCS} / 9-8-03$

Publication date: August 31st 2019

\section{INTRODUCTION}

Ethiopia continues to face high level of food insecurity and there are currently more than 10 million people who have been affected by drought. The deteriorating situation is compounded by high food prices; the cost of cereals has more than doubled in many markets since the beginning of the year, hampering the ability of many people to meet their most basic needs and impoverishing them further (WFP, 2009, Brown, L.,etal, 1990).

This resulted in poor performance of agricultural production for several years, to the extent that the country could not adequately feed its population from domestic production. The recurrent drought is worsening health problems such as communicable diseases, epidemic prone diseases, micronutrient deficiency, malaria, water and other vector borne diseases. In the past decades, demands for access to productive asset and particularly land became an important issue of those vulnerable and food insecure households (FDRE, 2003, Beyene Tadesse, 2008).

\subsection{Statement of the Problem}

In Ethiopia, the seriousness of food shortage problem varies from one area to another, depending on the state of the natural resources and the extent of food shortage (Webb et al., 1992). The land resources, mainly the soils and vegetation of the country have been highly degraded because of the interplay between environmental and human factors such as climate change, population pressure and the resultant over-cultivation of the land, deforestation, and overgrazing, technological and institutional factors (Tesfaye Zegeye etal, 1995, Yared Amare, 1999). These factors aggravated growing problem of food insecurity in Ethiopia. The dry land of Ethiopia comprises about $70 \%$ of the total landmass and $45 \%$ of the arable land. However, these areas contribute only $10 \%$ of the total crop production (Kidane, 1999). This amount of production is not sufficient to sustain the households residing in the 
area. The situation is aggravated by the fact that productivity in those areas declines at the rate of 3-4 percent per year (Tesfaye Lemma, 2003).

Offa District is declared as one of the 79 chronically food insecure and vulnerable District in South Nations and Nationalities of Peoples Region. It is one of the 12 Districts of Wolaita zone which is characterized as one most of densely populated area in Ethiopia (www.academia.edu). In which all major agro-ecological zones from lowlands ("kola") to cool temperate highlands ("wurch") are represented. The District has frequent crop failure and is vulnerable to food shortage. Due to this fact, the District is slowly slipping into vulnerability as the coping strategies are drying up (Ayalneh Bogale, 2002, CSA, 2007). Hence, it becomes essential to find out the causes of the food insecurity prevailing in this District and to assess the coping strategies under taken by the Households to cope up the food insecurity. No survey to the knowledge of the researcher has been conducted in Offa District in this regard. Hence, this research was conducted to assess the major causes of food insecurity and coping strategies of food in secure households in Offa District that would enable the researcher to recommend different coping strategies, its implementations to mitigate the food insecurity and the challenges and opportunities related with coping strategies that prevails in the study area.

\subsection{Objective Of The Study}

\subsubsection{The General objective of the study}

The general objective of this study is to explain the major causes of food insecurity and coping strategies of food insecure households in Offa District, Wolaita Zone, South Nations Nationalities and Peoples Region.

\subsubsection{The specific objectives of the study}

The specific objectives of this study are:

1. To analyze the major causes for food insecurity at household level in the study area

2. To assess the coping strategies of the farm households to mitigate food insecurity in the study area

3. To assess the challenges and opportunities related with coping strategies in the study area

\subsection{Significance of the Study}

Those food insecured households will be benefited from this study. As there is no any detailed survey undertaken in the study area, this study would be a base-line for other such studies in the zone and other places in the country that have similar demographic, socio-economic and institutional factors. It is also hoped that this research will throw some light on the possible reasons, motivations and causes behind diversified modes of coping strategies in the rural area.

Moreover, in light of an increasing desire towards decentralized and localized development planning and management, this research is expected to demonstrate the importance of micro level enquiry to properly and this study could be a useful secondary source for similar studies to be undertaken in future. Furthermore, the study provides directions for further research, and also generates the updated information to the policy makers that would assist the food insecure households.

\subsection{Scope of the Study}

The study was conducted in Offa District, Wolaita Zone, South Nation Nationalities and peoples Region. The study covered and restricted to only three Kebeles namely Busha, Wachiga Esho and Geleko in the District due to available limited funding and logistic potential of the student researcher.

\section{RESEARCH METHODOLOGY}

\subsection{Research Design}

This was cross sectional community based study comprised of both triangulated quantitative and qualitative design in Offa District which is one of the 12 Districts of Wolaita Zone and located in the SNNPR Ethiopia.

\subsection{Participants of the Study}

Both primary and secondary data sources have been used in this study. The data on causes of food insecurity, coping strategies, challenges and opportunities of coping strategies were collected from primary sources including household respondents. Additionally, the qualitative data to support the survey were also obtained from keyinformants such as district head of food security, FSO, farmers, community elder, younger people, NGOs and the FGD was conducted with FSO, model farmers, NGOs, community elders, young people, small holder farmers using a checklist prepared for this purpose.

\subsection{Sampling Techniques}

Offa District was purposively selected because the researcher know more about the area and it is one of the declared food insecure District in SNNPR (south nations nationalities and peoples region) among 79 selected chronically 
food in secured Districts which is supported by productive safety net program (www.academia.com), and those people who are living with their food insecurity have their own coping mechanisms. As the food insecurity status is widespread in all Kebeles of the District, 3 Kebeles were purposively be selected by considering the agroecology zones and vulnerability to the problem based on the information obtained from the District agriculture and rural development office food security program head. From several approaches to determine a sample, this study was applied a simplified formula by Yamane (Yamane, 1967 cited in Glen,1992) to determine the required sample size at $95 \%$ confidence level and level of precision $8.8 \%(0.088) n=\frac{N}{1+N(e) 2} \quad$ where, $\quad n=$ is sample size, $\mathrm{N}=$ is the population (total household) and $\mathrm{e}=$ the level of precision

Therefore, $\frac{3387}{1+3387(0.088) 2}=$ accordingly the result of Household sample size is 125. Among these sample Household Heads $20 \%$ of the sample Households Heads were Female Households Heads to make the sample population gender sensitive.

\subsection{Tools of Data Collection}

The FGD in each of the three kebeles has conducted, each of FGDs consists of eight participants (Food Security Organizations, model farmers, NGOs, community elders, young people, small holder farmers) and totally three FGDs were conducted. The selection of participants for FGDs was based knowledge, staying time in the area, institutional and occupational criteria. To get saturation of the information, there were also sessions for interviewing concerned bodies including the District head of food security, FSO, farmers, community elder, younger people, NGOs of the District through In-depth interview.

\subsection{Data Analysis Methods}

Both primary and secondary data collected for this research was organized and analyzed systematically by means of data organization through both quantitative and qualitative method of data analysis and triangulated as well as the researcher checked the reliability of data gathered from both primary and secondary sources.

Accordingly, the quantitative data acquired through close-ended questionnaire items was organized and displayed in tables to be analyzed quantitatively through the application of statistical techniques of percentage and frequencies. While the qualitative data obtained and elicited through open-ended questionnaire items were obtained from Focus Group Discussions (FGDs) and key informants were analyzed through narration and qualitative descriptions. Finally the conclusion and recommendations of the study were given.

\section{RESULTS AND DISCUSSION}

All the 125 households and 7 interviewees were responded $100 \%$, while out of planned 24 participants for the focus group discussion, 19 were participated. These indicate that $97.4 \%$ of the them were responded.

\section{Socio demographic characteristics of households}

The findings of survey households in the (table 4.2) shown that, majority of respondents were male headed households and married groups of the study area. From the sample households 101(80.8\%) were male households compared to female households, which were 24(19.2\%).From the sampled household respondents almost 92(73.6\%) were married and the remaining 5(4\%), 4(3.2\%), 24(19.2\%) respectively were single, divorced and widow /widower. From among 125 sampled households, 40(32\%) of the respondents were between the age 18-35, whereas $70(56 \%)$ were between 36-60 and the rest 3(2.4\%) and $12(9.6 \%)$ were found age below 18 and above 60 years. From the sampled 125 households, 66(52.8\%) of the respondents cannot read and write $28(22.4 \%)$ were read and write and the remaining $30(24 \%)$ and $1(0.8 \%)$ of the respondents have elementary and secondary and above educational level. The survey findings on table 4.3 showed that, $71(56.8 \%)$ of the households respondents said that they have no livestock production whereas $38(30.4 \%)$ of the households have 1-4 livestock and $16(12.8 \%)$ of the households have livestock above 4. Findings on the table 4.3 indicated that, 116(92.8\%) of the household responded that, intercropping is dominant agricultural practices which was used. And they said that, the use of intercropping practices enhance the long-term sustainability of soils and improve the resilience of crops to solve food shortage and the rest $9(7.2 \%)$ were not using intercropping the agricultural production. The finding in Botswana also supports this result, where diversification and fiber crops was indicated to have improved the individual smallholder's income, helped them to hedge reduced impacts from price fluctuations, protection against diseases and reduced food shortage (Glantz, 1987). [Table1 below] 
Table 1Socio demographic characteristics of households in Offa District Wolayta Zone, 2014

\begin{tabular}{|c|c|c|c|}
\hline \multirow{6}{*}{$\begin{array}{l}\text { Variables } \\
\text { Marital } \\
\text { households }\end{array}$} & Category & Frequency & \multirow{2}{*}{$\begin{array}{l}\text { Percent } \\
4\end{array}$} \\
\hline & Single & 5 & \\
\hline & Married & 92 & 73.6 \\
\hline & Divorced & 4 & 3.2 \\
\hline & widow/widower & 24 & 19.2 \\
\hline & Total & 125 & 100.00 \\
\hline \multirow[t]{5}{*}{ Age of households } & $<18$ & 3 & 2.4 \\
\hline & $18-35$ & 40 & 32 \\
\hline & $36-60$ & 70 & 56 \\
\hline & $>60$ & 12 & 9.6 \\
\hline & Total & 125 & 100.0 \\
\hline \multirow[t]{3}{*}{ Sex of households } & Male & 101 & 80.8 \\
\hline & Female & 24 & 19.2 \\
\hline & Total & 125 & 100.0 \\
\hline \multirow{5}{*}{$\begin{array}{l}\text { Educational } \\
\text { households }\end{array}$} & Cannot read and write & 66 & 52.8 \\
\hline & Read and write & 28 & 22.4 \\
\hline & Primary(1-8) & 30 & 24 \\
\hline & Secondary(9-12\&above) & 1 & 0.8 \\
\hline & Total & 125 & 100.0 \\
\hline \multirow[t]{4}{*}{ Household size } & $<5$ & 30 & 24 \\
\hline & $6-10$ & 61 & 48.8 \\
\hline & $>10$ & 34 & 27.2 \\
\hline & Total & 125 & 100.00 \\
\hline \multirow{4}{*}{$\begin{array}{l}\text { Residing in the area in } \\
\text { number of years lived of } \\
\text { households }\end{array}$} & $1-5$ & 1 & 0.8 \\
\hline & $6-10$ & 8 & 5.6 \\
\hline & $>10$ & 116 & 92.8 \\
\hline & Total & 125 & 100.0 \\
\hline \multirow{4}{*}{$\begin{array}{l}\text { Occupation of households } \\
\text { farmer }\end{array}$} & Merchant & 113 & 90.4 \\
\hline & Civil servant & 9 & 7.2 \\
\hline & Total & 3 & 2.4 \\
\hline & & 125 & 100.0 \\
\hline \multirow{5}{*}{$\begin{array}{l}\text { Hectare of } \\
\text { households }\end{array}$} & $<1$ hectare & 75 & 60 \\
\hline & 1-4hectare & 40 & 32 \\
\hline & $>4$ hectare & 7 & 5.6 \\
\hline & landless & 3 & 2.4 \\
\hline & Total & 125 & 100.0 \\
\hline \multirow{5}{*}{$\begin{array}{l}\text { Average crop production of } \\
\text { household }\end{array}$} & $<5$ & 88 & 70.4 \\
\hline & $5-10$ & 28 & 22.4 \\
\hline & $11-15$ & 9 & 7.2 \\
\hline & $>15$ & - & - \\
\hline & Total & 125 & 100 \\
\hline \multirow[t]{4}{*}{ Production } & Decreasing & 104 & 83.4 \\
\hline & Increasing & 15 & 12 \\
\hline & The same & 6 & 4.6 \\
\hline & Total & 125 & 100 \\
\hline \multirow[t]{3}{*}{ Intercropping } & Yes & 116 & 92.8 \\
\hline & No & 9 & 7.2 \\
\hline & Total & 125 & 100 \\
\hline \multirow[t]{4}{*}{ Livestock production } & No livestock & 71 & 56.8 \\
\hline & 1-4 livestock & 38 & 30.4 \\
\hline & $>4$ livestock & 16 & 12.8 \\
\hline & & 125 & 100 \\
\hline
\end{tabular}

Causes of household food insecurity

This study revealed that the major perceived causes of food shortages and production deficit, the sample households were with shortage of land, lack of input supply, climatic problem, shortage of water. Additionally, the traditional farming practice, poor performance, health condition of farmers, lack of soil fertility, inefficient development agent support...etc also can affect the food security in the study area, which have greatly affected 
the sustainability of production and productivity and made the study area more vulnerable and chronically food insecure.

Similarly, according to the interview and with the selected FGDs, the insect and pest infestation is another important biological factor that has been negatively affecting and limiting agricultural production in some of the study area.

The most vulnerable social groups by food shortage

As indicated on table 4.5 below, the $83.3 \%$, and $66.6 \%$ of the respondents suggested that, children and mothers are most vulnerable to the food shortage whereas on average $50 \%$ and $50 \%$ of the respondents suggested that, the poor and landless respectively are affected most by the events. On the other hand, $33.3 \%$ and $33.3 \%$ of the respondents suggested that the large family and fathers are affected by the problem. This is in line with study done in India and Wollo(Chung, K.etal, 1997 Dagnew Eshete, 1994)

Table 2 Vulnerability level of Social Groups by food shortage

\begin{tabular}{lllllll}
\hline Vulnerable group & Poor & Landless & Children & Mother & Large family & Father \\
Food Security Office Head & $\mathrm{X}$ & $\mathrm{X}$ & $\mathrm{X}$ & $\mathrm{X}$ & - & - \\
Farmers & - & - & $\mathrm{X}$ & $\mathrm{X}$ & $\mathrm{X}$ & $\mathrm{X}$ \\
FSO & - & $\mathrm{X}$ & $\mathrm{X}$ & - & - & - \\
Aged peoples & $\mathrm{X}$ & - & - & $\mathrm{X}$ & $\mathrm{X}$ & - \\
Young peoples & - & $\mathrm{X}$ & $\mathrm{X}$ & - & - & $\mathrm{X}$ \\
NGOs & $\mathrm{X}$ & - & $\mathrm{X}$ & $\mathrm{X}$ & - & - \\
Total & 3 & 3 & 5 & 4 & 2 & 2 \\
Percent & 50 & 50 & 83.3 & 66.6 & 33.3 & 33.3 \\
\hline
\end{tabular}

\section{The major coping strategies of food insecured households during food shortage}

Farm level adaptations arise from the farmers' perception of changing conditions. In the study areas, food insecured households have practiced different coping strategies to overcome the consequences to food insecurity thus far and to manage their future patters. Farming is the primary occupation for $90.6 \%$ of the sampled households although they combine some level of non-farming income sources. The high degree of dependence on farming activities calls for major adaptation to happen in the farming sector as this sector is directly affected by the different food shortage problems. This finding is consistent with study conducted in national level on coping strategies for food insecurity (Kidane Georgis, 1999).

In line with this, as indicated on [table 2], the present study identified that the food insecure households major coping mechanisms that most of time peoples practice to solve their problem in the study area when they face food shortage were engaging in labor work, livestock sale, migration to urban areas, relaying on remittance from relatives, limiting family size, sale of wood, sale of charcoal, requesting grain loan, reducing food consumption and begging. This consistent with study done in Diredawa and North Shewa(Ayalew Y, 2003, Abebaw S, 2003)

Table 3 Coping strategies among households in Offa district Wolayta zone 2014

\begin{tabular}{llllllll}
\hline Coping strategies & Level of cont. & No & V/low & Low & High & V/High & Total \\
& & 0 & 1 & 2 & 3 & 4 & \\
Migration to urban areas & Frequency & - & 5 & 25 & 80 & 15 & 125 \\
& Percent & - & $4 \%$ & $20 \%$ & $64 \%$ & $12 \%$ & $100 \%$ \\
Engaging in labor work & Frequency & - & 8 & 17 & 62 & 38 & 125 \\
& Percent & - & $6.4 \%$ & $13.6 \%$ & $49.6 \%$ & $30.4 \%$ & $100 \%$ \\
Livestock sales & Frequency & - & 16 & 47 & 45 & 17 & 125 \\
& Percent & - & $12.8 \%$ & $37.6 \%$ & $36 \%$ & $13.6 \%$ & $100 \%$ \\
Requesting grain loan & Frequency & 7 & 32 & 68 & 18 & - & 125 \\
Relaying on remittance & Percent & $5.6 \%$ & $25.6 \%$ & $54.4 \%$ & $14.4 \%$ & - & $100 \%$ \\
relatives & Frequency & 11 & 12 & 23 & 64 & 15 & 125 \\
Sale of wood & Percent & $8.8 \%$ & $9.6 \%$ & $18.4 \%$ & $51.2 \%$ & $12 \%$ & $100 \%$ \\
Sale of Charcoal & Frequency & - & 12 & 79 & 29 & 5 & 125 \\
Reducing food consumption & Percent & - & $9.6 \%$ & $63.2 \%$ & $23.2 \%$ & $4 \%$ & $100 \%$ \\
& Frequency & 7 & 58 & 43 & 17 & - & 125 \\
Limiting family size & Percent & $5.6 \%$ & $46.7 \%$ & $34.4 \%$ & $113.6 \%$ & - & $100 \%$ \\
& Frequency & - & 5 & 72 & 26 & 22 & 125 \\
Begging & Percent & - & $4 \%$ & $57.6 \%$ & $20.8 \%$ & $17.6 \%$ & $100 \%$ \\
& Frequency & - & 8 & 32 & 61 & 24 & 125 \\
& Percent & - & $6.4 \%$ & $25.6 \%$ & $48.8 \%$ & 19.2 & $100 \%$ \\
& Frequency & 107 & 13 & 5 & - & - & 125 \\
& Percent & $85.6 \%$ & $10.4 \%$ & $4 \%$ & - & - & $100 \%$ \\
\hline
\end{tabular}




\section{CONCLUSION AND RECOMMRNDATION}

In general, the overarching stressors that are enhancing societal vulnerability to crisis are shortage of land, shortage of water, climatic problem, lack of input supply, the traditional farming practice, poor performance and health condition of farmers, unemployment, lack of soil fertility...etc as the main causes of food shortage in the study area, that have greatly affected the sustainability of production and productivity and which made the study area more vulnerable and chronically food insecure. Accordingly, to improve the households' food security in the District; the highly degraded part of the area should be rehabilitated and the existing land resources should be protected.

Accordingly, soil and water conservation activities, such as gully treatments, establishment of nurseries and a forestation/reforestation are highly recommended. Expanding small scale irrigation and water harvest technology is highly recommended and the involvement of institutions, farmers and other concerned bodies on early warning and robust contingency planning is crucial. Promoting the attitude towards using effective level of fertilizer input under increasing land scarcity, improving the efficiency of inorganic fertilizer and promoting sustainable cropping practices is crucial to reduce social vulnerability to food insecurity. Enhancing and expanding rural credits to subsistence farmers in the area should be one of the primary areas of interventions. Rural credit service can help farmers in solving capital problem to buy farm oxen, modern farm inputs, use for trade, off-farm activities, and further enhancing use of technologies. Applying different crop species in the farm is basic and primary concern to increase the soil fertility, diversification and production, so that farmers recommended using different crop species to improve yield.

\section{REFERENCES}

Abebaw S., 2003. Dimensions and Determinants of Food Security among Rural Households in Dire Dawa, Eastern Ethiopia. A M.Sc. Thesis presented to the School of Graduate Studies of Alemaya University, Alemaya. 152p.

Adugha Eneyew B., 2008 Livelihood strategies and food security in Wolaita, SNNPR Ethiopia: The Case of Boloso Sore. Thesis presented to the School of Graduate Studies of Alemaya University

Anderson, 1997. 2020 Vision for Food, Agriculture, and the Environment in South Africa. In: Lawrence Haddad (ed.). Achieving Food Security in South Africa New Challenges, New Opportunities, IFPRI. Washington DC

Ayalew Y, 2003. Identification and Intensity of Food Insecurity and Coping Strategies of Rural Households in North Shoa: The Case of Lalomama. A M.Sc. Thesis presented to the School of Graduate Studies of Alemaya University. 221p.

Ayalneh Bogale, 2002. Land Degradation, Impoverishment and Livelihood Strategies of Wolaita Zone: WZFEDO: Wolaita

Ashimogo, G., and J. Hella, 2000. Deagrarinisation, household level food Security and Environment: The case of Iringa Region. A paper presented for the first RLDS International policy Research Workshop, Addis Ababa, 14-15, April, 2000.

Bazabih Emana, 2000. The Role of New Varieties and Chemical Fertilizer under Risk: The Case of Small holders in Eastern Oromia, Ethiopia. Ph.D dissertation. University of Hanover, Shaker Verlug.

Beyene Tadesse, 2008. Meauring validity in Food grain prices and its impact on the Demand for fertilizer and improved seeds in Cereal production in Ethiopia. Eth. J.of.Agrc. Econ. 7(1), 1-29.

Bonnard, P., 1999. Increasing the Nutritional Impacts of Agricultural Interventions. A paper presented at the Horn of Africa workshop on Agricultural policy, Resource Access and Human Nutrition, Addis Ababa, 3-5 November 1999.

Brown, L., C. Flavin and H. Kane, 1990. State of the World 1990. WW.Norton: New York.

Casley D.J. and D.A. Lary, 1987. Data Collection in Developing Countries, Clarendon Press: Oxford.

Chung, K., Haddad, L., Ramakrishna, J., and F. Eiely, 1997. Identifying the Food Insurance: The Application of Mixed method Approaches in India. IFPRI: Washington DC.

CSA (Central Static Authority). The 2007 Population and housing census of Ethiopia result for SNNPR, abridged Statistical report. CSA: Hawassa.

Davies, S., 1994. Are Coping Strategies a cop out? Nutrition paper of the Month. UNICEF: New York.

Dagenew Eshete, 1993. Food Shortages and Households Coping Strategies by Income Groups; A Case Study of Wolaita district in Southern Ethiopia. Save the children (UK): Addis Ababa.

Dagnew Eshete, 1994. Food Grain Marketing, distribution Mechanisms and problems in Wollo and Adjacent Administrative Zones: Implications for Household Food Security and policy. Save the children (UK): Addis Ababa.

Dagnew Eshete, 1995. Seasonal and Exceptional Food shortage. Their Causes and Socio- Economic Consequences: A case Study of Wolaita District in Southern Ethiopia. Save the children (UK): Addis Ababa.

Dagnew Eshete, 1997. Training programme on food security and Vulnerability. IDCOF: Dessie.

Debebe H., 1995. Food Security: A Brief Review of Concepts and Indicators. pp. 1-18. Proceedings on the inaugural and first annual conference of the Agricultural Economics Society of Ethiopia. Addis Ababa, 
Ethiopia, 8-9 June 1995. Agricultural Economics Society of Ethiopia.

Devereux, S., 1993. Goats before Ploughs: Dilemmas of Household Response Sequencingduring Food Shortages. IDS Bulletin, 24(4): 52-59.

Dore, Anna R.,Linda S,. Adair and Barry M. Popkin P, 2003. Low income Russian Families Adopt Effective Behavioral Strategies to Maintain Dietary Stability n Times of Economic crisis Journal of Nutrition, 33, 3469 3475.

Edie, W.B., G.Holmoe - ottesen, A. Oshaug, D. Perea, S. Tilakaratna and M. Wandel, 1986. Introducing Nutritional Considerations into Rural Development programs with focus on Agriculture.Towards Practice. University of Oslo: Oslo.

Ellis, F., 2000. Rural Livelihoods and Diversity in Developing Countries, Oxford University Press

FDRE (Federal Democratic Republic of Ethiopia), 2003.The New Coalition for Food Security Program. FDRE: Addis Ababa.

FAO, 1994. Proceeding from the Forum on Operationalzing Sustainable Livelihoods Approaches, ODI, Uk, London

FAO, 2008. Proceeding from the Forum on Operationalzing Sustainable Livelihoods Approaches, ODI, Uk, London

Federal Democratic Republic of Ethiopia (FDRE), 2003. The New Coalition for Food Security Program. Zero Draft. Volume 1. Addis Ababa, Ethiopia.

Frankenberger, T.R., and D.M. Goldstein, 1992. Linking Household Food security with Environmental Sustainability Through an Analysis of Coping Strategies. In Growing Our Future. Kumarian Press: New York

Frankenberger,T.R., Sutter, P., Amdissa,T., Alemtsehay,A., Mulugeta, T., Moges ,T., Alemayehu, S., Bernard,T., Spangler,T., Yeshewamebrat, E., 2007. Ethiopia: The Path to Self-Reliancy, Volume I: Final Report

Fron gilo, Edward A., Nusrat Choud Hury, Eva Charlote Ekstro, and Ruchira T. Naved ,2003. Understanding the experience of House hold Food insecurity in Rural Bangladesh leads to a measure different from that used in other countries journal of Nutrition, 133, 4158;4162.

Getachew Diriba, 1995. Economy at the crossroad: Famine and Food Security in Rural Ethiopia. Commercial Printing Enterprise: Addis Ababa.

Gezahegn Ayele, W. O., Steven and Eleni Gabre-Madhin, 2003. The State of Food Security and Agricultural Marketing. Proceeding of a policy Forum of The Ethiopian Development Research Institute (EDRI) and The East African Food Policy Network of the International Food Policy Research Institute (IFPRI). 15-16, May (2003), Addis-Ababa, Ethiopia.

Glantz, M.H., 1987. Drought and hunger in Africa: denying famine a future, Cambridge University Press.

Haddad, L., 1997. Human Nutrition in the Developing World. Ithaca: New York.

Hansen, A., 1986. Coping with Famine, Drought and War in Sub-Saharan Africa: Studies in Third World Societies 36 Natural Disasters and Cultural Responses, Published by: College of William and Mary Williamsburg, Virginia

Kidane Georgis, 1999. Agronomic Technique foe Higher and Sustainable Crop Production in the Dry Land Area of Ethiopia Food Security prospective, In: Taye Asefa (eds.): Food Security Through Sustainable Land use Proceedings of the First National Workshop of NOVIN, Addis Ababa.

Kifle Lemma and Yosef Gebrehiwot, 1999. The Food Security Situation in Ethiopia.Concepts, Status and Trends. In: Taye Assefa (ed.): Food Security through Sustainable Land use. Proceeding of the first National Workshop of NOVIN Partners.Forum on Sustainable land use. NOVIN, Addis Ababa.

Maxwell, D., Ahiadeke, C., Levin, Armar. Klemesu, M., Zakariah, S. and Lamptey, C.M., 1994. Alternative Food Security Indicators: Revisiting the Frequency and Severity of coping Strategies: Food Policy 24, 411-429.

Maxwell, S., 1996.Measuring Food Insecurity: The Frequency and Severity of Coping Strategies. Food Policy, 21(33): 291-303.

Ministry of Finance and Economic Development (MoFED), 2002. Sustainable Development and Poverty Reduction. Zero Draft Ministry of Finance Economic Development, Addis Ababa. (Unpublished)

MoFED, 2006, Ethiopia: Building on Progress: A Plan for Accelerated and Sustained Development to End Poverty (PASDEP) (2005/06-2009/10) Volume I: Main Text

Molnar and Joseph J., 1999. Sound Policies for Food Security: The role of culture and Social Organisation Review of Agricultural Economics, 21(2); 489-498

Mulugeta T., 1992. Determinants of Household Food Security in Eastern Oromia, Ethiopia: The Case of Boke District of Western Hararghe Zone. A M.Sc. Thesis presented to the School of Graduate Studies of Alemaya University. $151 \mathrm{p}$.

ODI, 2003. Understanding Livelihoods in Rural India: Diversity, Change and Exclusion, UK.

Offa Woreda Agriculture and Rural Development Office Annual Work Report (ARDO 2012 and 2013 Annual Report) 
Oldewage-Theron, wilna H., Emsie G. Dicks and Carin E. Napier, 2006. Poverty, House hold food insecurity and Nutrition; Coping strategies in an informal settlement in Vaal Triangle ; South Africa in Public Health . Vol 120,No.9,pp 795-804

Parry, M. L. and Duinker, P. N, 1990. "Agriculture and Forestry" In: J. McG. Tergart, G.W.Sheldon and D. C. Griffiths, 1990. Climate Change-The IPCC Impacts Assessment WMO/UNEP Inter-governmental Panel on Climate Change. Canberra: Australian Government Publishing Service. pp 45.

Reutlinger, S, 1987. Food security and poverty in developing countries: In policy: Integrating supply, distribution and consumption, edited by J. Gittinger and Baltimore: Johns Hopkins.

Sen, A., 1981. Poverty and famine: An essay on entitlement and deprivation. Claredon Press: Oxford.

Smith, L C., Alderman, H and Aduayom, D., 2006, Food Insecurity in Sub-Saharan Africa New Estimates from Household Expenditure Surveys: International Food Policy Research Institute Washington, DC.

Tassew Woldehanna, 2008. Correlates of poverty in Rural and Urban Ethiopia: Department of

Economics Addis Ababa University, Ethiopia, Eth. J. of Agric. Econ. 7(1), 49-81

Tesfaye Lemma, 2003. Diversity in livelihoods and farmers strategies in Hararghe highlands, Eastern Ethiopia, University of Pretoria, South Africa.

Tesfaye Kumbi, 2005.household Food Insecurity in Dodota-Sire District, Arsi Zone: Coping Strategies and Policy options. A Thesis Presented to the School of Graduate Studies Alemaya University

Tesfaye Zegeye and Debebe Habtewold, 1995. Food Security: A Situation Analysis. In: Mulat, D.; Wolday, A.; Ehui, S. and Tesfaye, Z. (ed.): Food Security, Nutrition and Poverty Alleviation in Ethiopia: Problems and Prospects. Proceedings of the Inaugural and First Annual Conference of the Agricultural Economics Society of Ethiopia, Addis Ababa, Ethiopia.

Webb, P., Braun, J. and Yohannos, 1992. Famine in Ethiopia: Policy Implication Coping Failure at National and Household Levels. IFPRI: Washington DC.

World Bank, 1986. Poverty and Hunger: Issues and Options in Developing Countries. World Bank: Washington DC.

World Food Programme (WFP), 2009. Baseline Food Security Analysis in Iraq, WFP Iraq country office.

Yamane, T., 1967. Statistics, An Introductory Analysis, $2^{\text {nd }}$ Ed., New York

Yared Amare, 1999. Household Resources, Strategies and food security in Ethiopia. Study of Amhara households in Wogda, Northern Showa. Addis Ababa University: Addis Ababa. 